\title{
SHEAR ZONE CONTROL ON THE EMPLACEMENT OF GRANITOID MAGMAS: AN EXAMPLE FROM THE JAPI COMPLEX, SERIDÓ BELT, NE BRAZIL
}

\author{
MARIA HELENA BEZERRA MAIA DE HOLLANDA*, EMANUEL FERRAZ JARDIM DE SÁ, ANTONIO CARLOS GALINDO \\ \& ZORANO SÉRGIO DE SOUZA
}

\begin{abstract}
RESUMO CONTROLE DE LOCALIZAÇÃO DE MAGMAS GRANITÓIDES POR ZONAS DE CISALHAMENTO: O EXEMPLO DO COMPLEXO JAPI, CINTURÃO DO SERIDÓ, NE DO BRASIL O complexo de Japi, localizado no domínio oriental da Faixa Seridó (NE do Brasil), é um corpo intrusivo composto com forma en cornue, compreendendo uma suite mais antiga, de granitos alcalinos sintectônicos, e suites mais jovens, sin a tardi-tectônicas, de rochas básicas a intermediárias shoshoníticas e granitóides de afinidades monzonítica e cálcio-alcalina. Feições como as formas das intrusões individuais e sua localização em sítios transtracionais; a ocorrência de sheets de espessura métrica a decimétrica, alojados ao longo de bandas de cisalhamento, superfícies axiais de dobras, encurvamentos e estruturas de pull-apart semi-frágeis ou frágeis; transições entre fabrics viscosos e de estado sólido nos corpos plutônicos, exibindo a mesma orientação e cinemática com respeito às estruturas nas encaixantes, são todas indicativas de um controle, no alojamento das várias suites, de uma zona de cisalhamento oblíqua, transcorrente + extensional, localizada na vizinhança do complexo. Essa estrutura, denominada como a zona cie cisalhamento de Japi, $e ́$ correlacionada ao estágio principal da deformação Brasiliana de alta temperatura, na região.

Palavras-chave: Brasil, complexo Japi, tectônica, estrutura, petrografia, geoquímica

ABSTRACT The Japi Complex, in the eastern gneiss-migmatite domain of the Serido Belt (NE Brazil), is a composite, en comae-shaped intrusive body, comprising an older syntectonic alkalic granite and late, syn- to late-tectonic basic-to-intermediate shoshonitic plutons and granitoids of monzonitic and calc-alkalic affinities. A persistent control on the emplacement of the various suites by a nearby oblique, strike-slip + extensional is suggested by several features. Among them are: shapes of individual intrusions and their location in transtensional sites; metricto decimetric-thick sheets emplaced along shear bands, fold axial surfaces and semi-brittle to brittle pull-apart and transtensional jogs and transitions between viscous- to solid-state fabrics in the plutons, bearing the same orientation and kinematics as in their country rocks. This structure, the so-called Japi shear zone, is correlated to the main, high-temperature stage of the Brasiliano orogeny in this region.

Keywords: Brazil, Japi Complex, tectonics, structure, petrography, geochemistry
\end{abstract}

INTRODUCTION Outstanding features of the Brasiliano orogeny in the Seridó Belt (NE Brazil) are the huge amount of granitoid plutons and a complex shear zone network (Fig. 1). This kind of setting is ideal to test the hypothesis of shear zone control on magma emplacement, a concept accepted by many authors but still much debated in the literature (e.g. Second ISGAM Abstracts with Programs volume, edited by Ferreira \& Sial 1997 and Bouchez et al. 1997). The present paper aims to contribute to this important issue.

In the Seridó Belt (hereafter abbreviated as SB), different types of granitoids have been documented by petrographic and geochemical data. Among them, subalkalic porphyritic granites (the so-called Itaporanga-type;Almeida et al 1967 Galindo et al 1995,1997)isavery common type. Most of these suites display features of syntectonic intrusions and occur adjacent to major, dominantly transcurrent shear zones (Jardim de Sá et al. 1986, 1987, Archanjo et al. 1992)

The Japi alkalic complex (Hollanda et al. 1996, Hollanda 1998) is located in the eastern gneiss domain of the $\mathbf{S B}$, also referred to as the São José de Campestre block. Unlike the late- to post-tectonic setting usually argued for alkalic suites, the different and successive granitoid suites that make up this complex intrusive body show a persistent control by shear zone structures.

THE JAPI COMPLEX: TECTONIC SETTING AND RELATIVE CHRONOLOGY OF INTRUSIONS The Japi complex (Fig. 1) occurs adjacent to an important NW-trending mylonite zone (the Japi shear zone, JSZ) with sinistrai displacement sense in the horizontal surface. The intrusion displays an en cornue shape (like many other examples in the $\mathbf{S B}$ ), which attests to its deformation and the shear zone kinematics. Preliminary $\mathrm{U}-\mathrm{Pb}$ and $\mathrm{Rb}-\mathrm{Sr}$ age dating (Hollanda 1998) allow to correlate the pluton and the JSZ to the main Brasiliano-orogeny deformation phase $\left(\mathrm{D}_{3}\right)$ in the $\mathrm{SB}, \mathrm{ca} .580 \pm 30 \mathrm{Ma}$ (deformation phases named according to Jardim de Sá 1994, 1995).

The country rocks of the Japi complex are the gneisses and migmatites of the regional "basement" complex of Paleoproterozoic to Archaean age (Dantas et al. 1995). The gneisses display at least two main generations of structures $\left(\mathrm{D}_{1}, \mathrm{D}_{2}\right)$ pre-dating the pluton emplacement. Far from the JSZ, $\mathrm{D}_{2}$ originally recumbent folds and flat-lying mylonites with a NW-trending stretching lineation $\left(\mathrm{L}_{2}{ }_{2}\right)$ affect an early $\mathrm{S}$, gneissic banding.

Four plutonic suites are found in the main complex and as satellite intrusions, as well as late pegmatite and pink leucogranites. The main elliptical-shaped intrusion is made up by alkalic granites which bear a pervasive, solid-state SL (mostly S $>$ L) fabric. It is characterized by the shape-preferred orientation of quartz and feldspar, which display intracrystalline plasticity and therefore indicates that deformation oc- curred under $\mathrm{T}>450^{\circ} \mathrm{C}$. In some places, a regular magmatic layering (pyroxene and amphibole concentrates) is parallel to the solid-state foliation. This fabric accompanies the shape of the complex, with inward dips, being especially developed along its borders (Fig. 1). Furthermore, it correlates with the $\mathrm{D}_{3}$ structures in the country rocks, both in orientation and kinematics. Alkalic dikes are found crosscutting the basement gneiss pre-existing foliations $\left(\mathrm{S}_{1}, \mathrm{~S}_{2}\right)$. Within the pluton, metric- to decametric-thick septa of the country rocks follow the elliptical shape of the intrusion, defining a ring-like structure built up by intrusion of multiple granite sheets. The JSZ mylonites and associated structures in the basement $\left(\mathrm{D}_{3}\right)$, coeval with the granite emplacement, are also of high-temperature type, anatectic conditions being frequently reached. Pre- $\mathrm{D}_{3}$, fine-grained basic dikes suggest an important time break between $\mathrm{D}_{2}$ and $\mathrm{D}_{3}$.

A basic-to-intermediate (also known as "dioritic", since it is a common petrographic type, among others of more basic or more acid composition) suite occurs as: metric to decametric-long dikes and as satellite bodies (one close to the center, a second in the western margin of the main alkalic granite, and a third one occupying the southern tail of the Japi complex). Porphyritic granites (analogous to the "Itaporanga type" granites that are widespread in the SB; Jardim de Sá 1994, Galindo et al. 1995, 1997) commonly occur as dikes and as minor intrusions, either isolated or associated with the diorites, intruding the alkalic granite and the surrounding gneisses. The porphyritic granites and diorites show contact relations that indicate mingling and various stages of mixing between coeval basic and acid magmas, such as globular- to ellipsoidal-shaped basic and granite enclaves with crenulated, ill-defined margins; captured K-feldspar phenocrysts in the "diorite" host, and acicular plagioclase phenocrysts in quenched basic rocks.

Both suites usually display magmatic fabrics. $\mathrm{D}_{3}$ shear bands in the country rocks may continue, across the granite contacts, into a magmatic equivalent structure affecting the viscous fabric of the porphyritic granites. On the other hand, late, semi-brittle domino-type voids in the surrounding gneisses may be filled with veins of the porphyritic granite. These younger suites contain angular-shaped xenoliths of the basement gneisses and the alkalic granite, the latter already bearing its solid state foliation (correlated to the 83 structure in the country rocks). Along the JSZ and in a few other places, the diorites and granites are also affected by the solid state deformation related to the $D_{3}$ event. In all such cases, the solid-state fabric is parallel to the magmatic structure in these suites, and both of them may be correlated with the 03 event of the country rocks, in terms of orientation and kinematics. All these relationships attest to a syn- to late- $\mathrm{D}_{3}$ age for the basic-to-intermediate and porphyritic granite magmas, em-

Núcleo de Pesquisa/Programa de Pós-Graduação em Geodinâmica e Geofísica, Departamento de Geologia, UFRN, Campus, 59.072-970 Natal RN Brasil; fax (84) 2153806, e-mail: emanuel@geologia.ufrn.br; galindo@geologia.ufrn.br; zorano@geologia.ufrn.br

* present adress: Curso de Pós-Graduação em Geologia, Instituto de Geociências, UnB, 70.910-900 Brasília DF Brasil; fax (61) 3474062, e-mail: hollanda@guarany.unb.br 


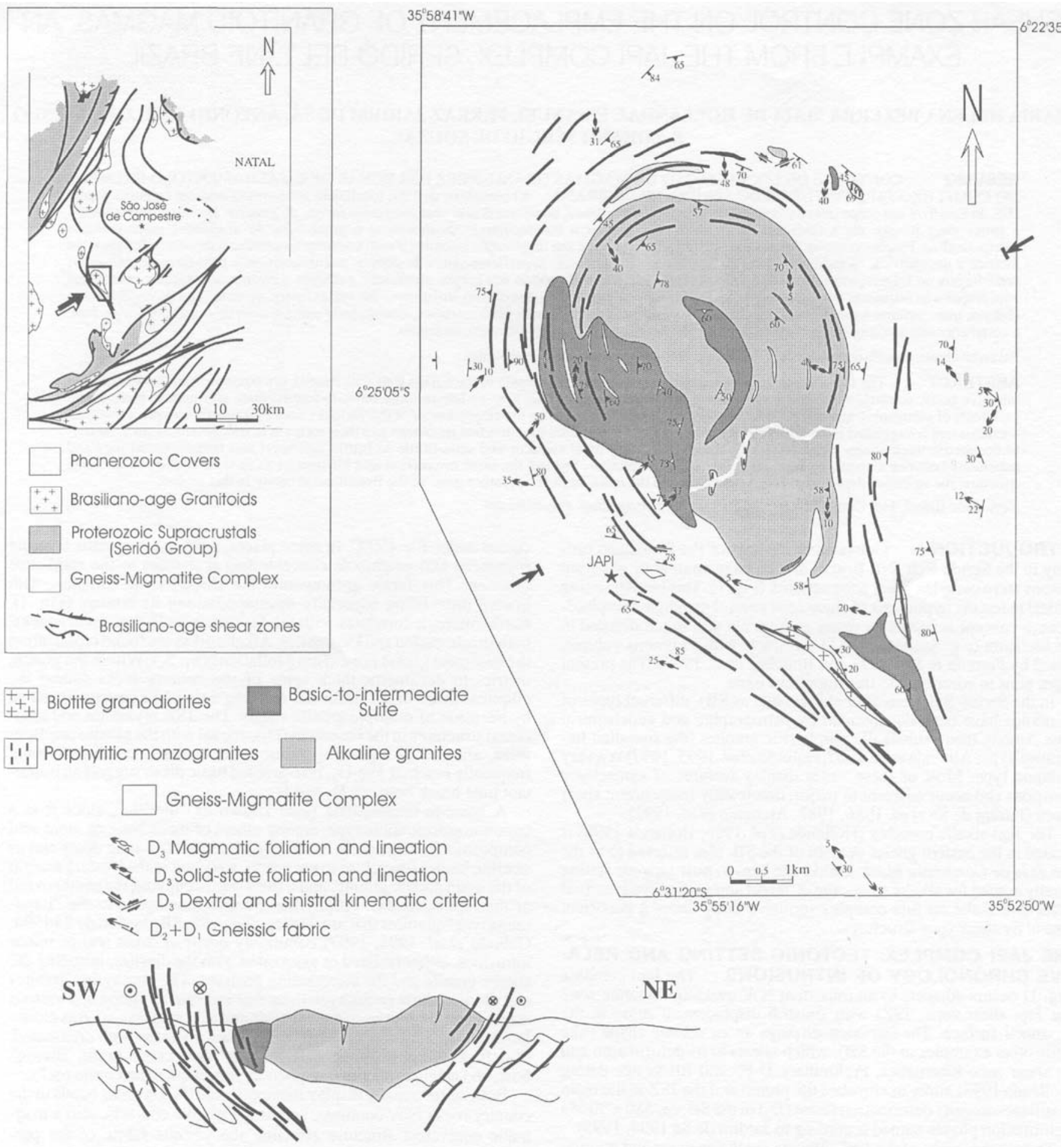

Figure1l-Geological map of the Japi complex. The inset shows its location and the geological framework of the eastern (São José de Campestre) gneiss-miginatite domain of the Seridó Belt, NE Brazil.

placed under declining $\mathrm{T}$ conditions, as shown by their control both by ductile or semi-brittle and brittle structures.

A suite of light gray, equigranular granodiorites appears to be slightly younger (or contemporaneous) as regards to the "diorites" and porphyritic granites, the same holding for pink microgranites and late pegmatites. These minor intrusions (mostly dikes) truncate or are just affected by low temperature (greenschist fades) mylonites, being associated essentially with semi-brittle or brittle structures.

PETROGRAPHIC AND GEOCHEMICAL DATA The alkalic suite comprises leucocratic syenogranites and subordinate quartz syenites (Fig. 2), with modal aegirine-augite (and subordinate hornblende) varying between 0.5 to $1.5 \%$, sometimes up to $6 \%$. Sphene, zircon, opaque minerals and apatite are the usual accessories. Besides the anhydrous, mafic mineralogy, R1-R2, TAS (Fig. 3) and other major element diagram confirm its oversaturated alkalic affinity. The complete modal and geochemical data sets may be found in Hollanda (1998).

Gabbro-norite is the most primitive member of the basic-to-intermediate suite, bearing a Fe-augite + plagioclase + hyperstene forsterite mineralogy. The suite differentiates to the dominant monzo- and quartz diorites, monzonites and quartz monzonites (Fig. 2), which contain amphibole and biotite as their main mafic phases (Fig. 2). Zircon, apatite, sphene and opaque minerals define the accessory mineralogy. This suite displays shoshonitic (mafic subalkalic) affinities in the $R_{1}-R_{2}$ and TAS diagrams (Fig. 3; also the Q-P diagram of Debon \& LeFort 
1983). They also show similarities with the "K-diorites" described by Guhon et al. (1972).

The porphyritic monzogranites (Fig. 2) contain K-feldspar phenocrysts and are additionally characterized by the assemblage biotite + amphibole + sphene, bearing monzonitic (felsic subalkalic) affinities (Fig. 3). Epidote, allanite, sphene, opaque minerals, zircon and apatite also occur as accessories. Even though the field evidence points to mingling and mixing phenomena between these granites and the K-diorites, the chemical data (see especially Fig. 4) clearly show that they are associated to different parent magmas.

Finally, the gray, fine-grained, biotite granodiorites display calc-alkalic trends in the above mentioned diagrams (Figs. 2, 3). Sphene, epidote, hornblende, allanite, zircon and apatite occur as accessory phases. The late pink, alkali-feldspar granites have an eutectic composition and frequent granophyric textures, which point to emplacement at shallow levels.

Harker diagrams (Fig. 4) are also useful in demonstrating that each suite is related to specific parent magma. Isotope determinations in progress $(\mathrm{Sr}, \mathrm{Nd})$ and trace element patterns, together with their general affinities, indicate that the JSZ controls and/or affects magma suites extracted from different, crustal and mantle sources.

Recently reported cases (Sial \& Ferreira 1988, Jardim de Sá 1994, Jardim de Sá et ai. 1996), the basic, shoshonitic magmas were extracted from an enriched lithospheric mantle source. The gray granodiorites and the porphyritic granites probably came from a crustal source with an intermediate composition. The alkalic pluton may have been derived from a $\mathrm{CO}_{2}$-fluxed source, either by direct melting of anhydrous, intermediate or basic granulite facies lower crust, either through fractionation of basic-to-intermediate magmas previously extracted from the underlying, enriched and probably heterogeneous mantle.

THE PLUTON SHAPE AND ITS CONTROL BY MAJOR STRUCTURES The en cornue shape of the Japi pluton poses the apparent paradox of infilling a flattening (XY) plane, instead of the more classical tension gashes typical of the upper crustal, brittle regime. Just like granitoid sheets alongside fold axial planes and foliation surfaces, this kind of situation appears to be rather typical of deformation under deep seated, high T conditions (e.g., Brown 1994).

Developed upon originally flat-lying $\left(D_{2}+D_{1}\right)$ fabrics in the basement, the JSZ folds these earlier structures and overprints a new fabric $\left(\mathrm{D}_{3}\right)$ comprising NE-dipping foliations and N- to NNE-plunging stretching lineations (Figs. 1,5). The sinistrai shear sense at the surface links with a down-dip component, the net picture being one of oblique extensional movement. The en cornue pluton shape correlates well with this kinematics, as also does the overall pattern of magmatic and solid state fabrics in the different granitoid suites. To the north, the JSZ swings and follows the northern border of the pluton, defining a transpressional termination.

At a larger scale, the space problem for this pluton is well accomplished by the extensional (transtensional) kinematics of the JSZ, possibly favored by an eventual ramp-and-flat geometry at depth. The negative Bouguer anomaly at Japi is displaced to the NE as regards to

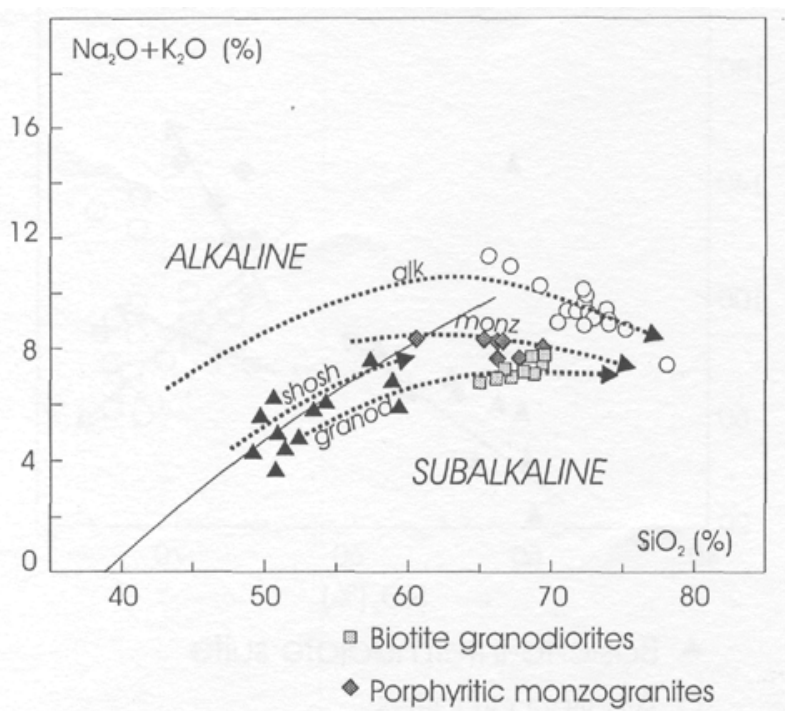

the alkalic granite location, being hardly reconciled with its inverted drop shape constrained by the inward-dipping foliation pattern. The best solution for modeling the gravity data (Hollanda et al. 1997, Hollanda 1998) is to assume another, larger granite body at depth, displaced to the N/NE as regards to the outcrop of the main Japi pluton, the former possibly emplaced along a buried flat of the JSZ. Space for the emplacement of the southern diorite satellite is easily solved by its location in the tail of the pluton, a macro-scale strain shadow zone.

In a more detailed view, the main alkalic granite and its western diorite satellite are not located in the JSZ high strain belt itself, instead being laterally displaced, eastwards from it, where major strain discontinuities are to be expected along the margins of the JSZ. Such strain discontinuities, possibly resolved by an interconnected network of hot fractures (boudin necks, R-and P-type shear bands), are thought to provide tectonic voids that enable magma transport and storage as successive sheets, according to a pumping mechanism as envisaged by D'Lemos et al. (1992). The heterogeneous deformation at the margin

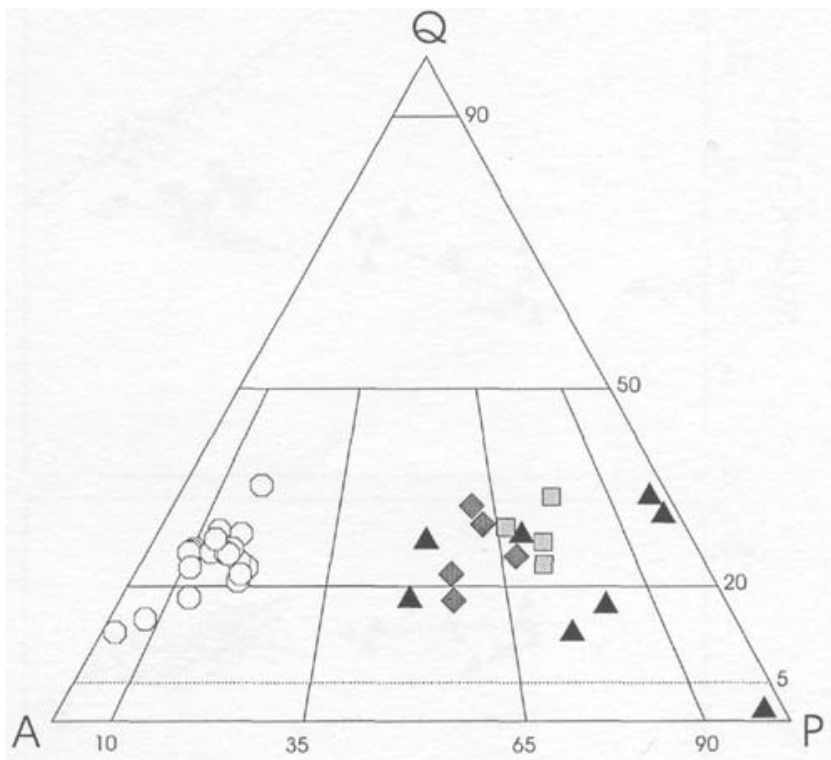

contrasts with the more homogeneously deformed, central high strain $\square$ Biotite granodiorites

$\Delta$ Basic-to-intermediate suite $\checkmark$ Porphyritic monzogranites ○ Alkaline granites

Figure 2 - Streckeisen's Q-A-P modal diagram of the different granitoid suites of the Japi complex. The samples from the alkalic suite were plotted using chemical data, according to the proposal of L Maitre (1976).

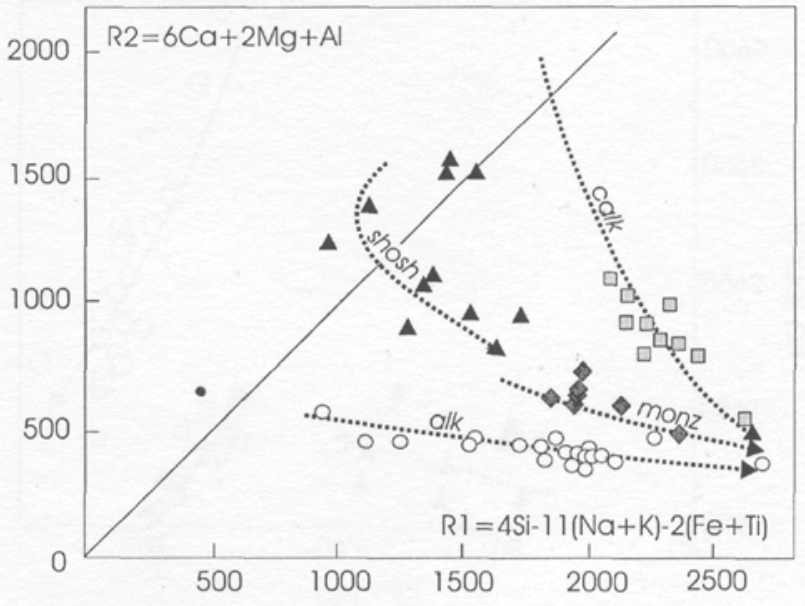

- Basic-to-intermediate suite

○ Alkaline granites

Figure 3 - TAS and Rj-Ri diagrams for the different granitoid suites of the Japi complex. Reference trends according to Lameyre (1987) and De La roche et al. (1980). 

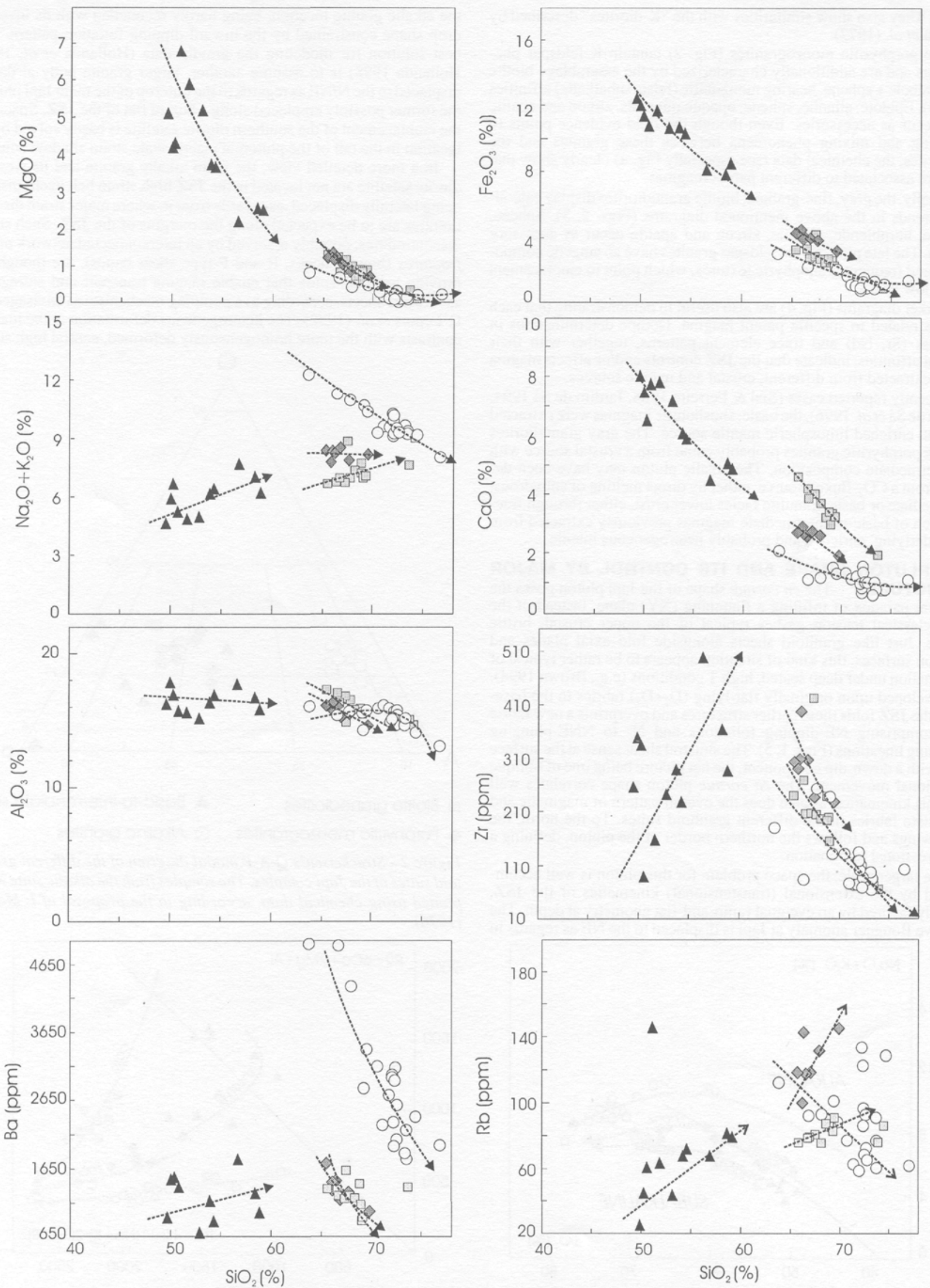

Biotite granodiorites

- Porphyritic monzogranites

- Basic-to-intermediate suite

- Alkaline granites

Figure 4 - Selected Barker major and trace element diagrams for the different granitoid suites of the Japi plulon. 
mylonitic belt, whose permeability is greater but essentially developed at a microscopic scale (Etheridge et al. 1983).

MINOR STRUCTURES AND FABRIC DATA Fabric data along the main, alkalic granite, records its deformation by the JSZ under high $\mathrm{T}$ conditions, immediately after emplacement (Hollanda 1998, synthesized in Fig. 5). Along its northern and NE borders, the alkalic granite shows a major component of flattening that can be explained by deformation at the transpressional, eastside termination of the JSZ. In the latter granitoid suites (diorites and porphyritic granites), a similar kinematic regime under decreasing temperature is attested by the common emplacement of dikes along conjugate, strikeslip/extensional semi-brittle shear zones and faults.

Along the JSZ, alkalic sheets and dikes are commonly emplaced in extensional, ductile $\mathrm{C}^{\prime}$ shear zones, attesting to the syntectonic timing of this plutonic event. Felsic mobilizates are also noticed along these meso-scale structures, confirming the ductile, deeper-seated environment during emplacement of the alkalic magma. Microtextural evidence for solid state deformation in the alkalic granites, as well as in dikes of diorites and porphyritic granites, include the strong preferred orientation of the mafic minerals, bending of the twinning lamellae of the plagioclase, bands of undulatory extinction, and ribbon texture in quartz. Fine-grained polycrystalline aggregates of quartz and feldspar attest to the high temperatures (amphibolite fades) reached during recrystallization of these rocks. Such characteristic contrast with those observed in the less deformed granitoids at the tail and the center of the main pluton, as shown by non-deformed quartz crystals and the near isotropic distribution of the mafic minerals.

CONCLUDING REMARKS Field data, both at macro and mesoscopic scales attest to the control of different granitoid batches and pulses by structures that can be correlated to the JSZ. Geochemical data allow characterizing different magma types controlled and/or affected by the shear zone, including mantle-derived melts. This point suggests that the JSZ is part of a major structure rooted at the lithospheric mantle level.

Structural data at different scales usually record deformation (both under viscous and plastic flow regimes) after magma emplacement as implied by the down-dip shear component, necessarily opposed to the upward movement of the magma batches; it is just in a few instances that preserved viscous shear criteria record upward flow. Semi-brittle and brittle structures controlling latter magma pulses keep the same kinematics as regards to the high temperature viscous to ductile stages Location of the major alkalic body and its western diorite satellite just besides the main mylonite belt is probably controlled by the frequency of meso- to macro-scale strain discontinuities along the boundary of the JSZ with its lower strain gneissic protoliths. A deep-seated granite root emplaced along an underlying flat of the JSZ better explains gravity data. A tectonic pumping model such as that proposed in the literature (D'Lemos et al. 1992) could have promoted upward magma migration. This point demands further modeling work but one may envisage that, besides the superimposed strain, the granite shape is mostly controlled by the orientation of the (local, regional) stretching lineation, opening spaces at high angle with, and making easier magma

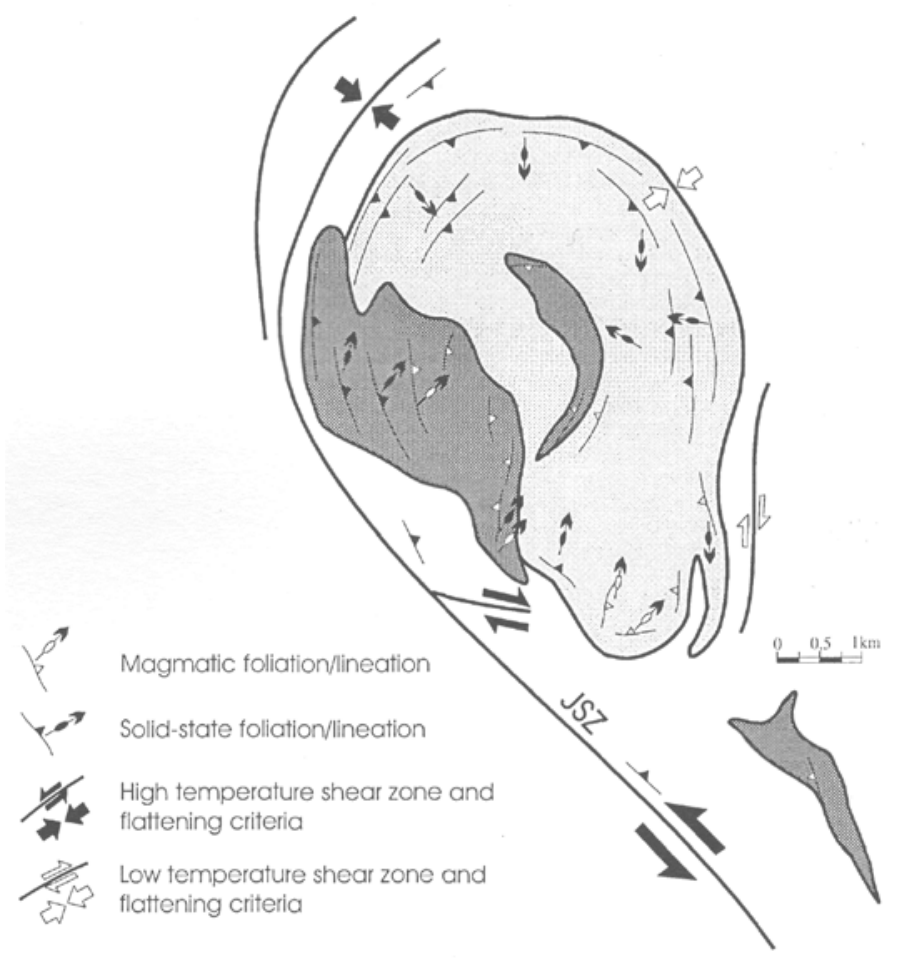

Figure 5 - Simplified structural map of the Japi complex.

migration along the foliation plane. The ring-like structure of the alkalic granite may reflect successive increments of opening and filling tectonic voids at the transpressional termination of the JSZ.

Acknowledgements This paper is based on the M.Sc. dissertation of MHBMH at the Programa de Pesquisa e Pós-Graduação em Geodinâmica e Geofísica - PPGG/UFRN, who acknowledges a CAPES scholarship. FINEP/PADCT and CNPq provided financial support for field and laboratory work, during which the assistance of D.L. Castro, J.A.M. Moreira, W.E. Medeiros, F.C. Alves da Silva, V.E. Amaro and R.S.C. Nascimento (all from PPGG/UFRN) was of great value. At different stages, the research benefited from discussions with I. McReath (IG/USP), R.I.F. Trindade (PPGG/UFRN, presently at the IAG/USP), J.L. Vigneresse (CREGU, France) and J.M. Lardeaux (Lyon, France). The CAPES/COFECUB program enabled the participation of the French colleagues in the research conducted in the Serido Belt. Finally, two anonymous reviewers greatly helped in improving this text.

\section{References}

Almeida, F.F.M. de; Leonardos Jr., O.H.; Valença, J. 1967. Granitic rocks of Northeast South America. In: Symp. GRanitic Rocks in South America. Recife, 1967, IUGS/UNESCO,41p.

Archanjo, C.J.; Olivier, Ph.; Bouchez, J.L. 1992. Plutons granitiques du Seridó (NE du Brésil): écoulement magmatique parallèle à Ia chaíne revele par leur anisotropie magnétique Bull Sac géol. France 163. 509-520.

Bouchez. J.L.; Hutton, D.H.W.; Stephens, W.E. 1997. Granite: from segregation of mel to emplacement fabrics. Dordrecht, Kluwer Academic Press. 368 p.

Beown, M. 1994. The generation, segregation, ascent and emplacement of granite magma: the migmatite-to-crustally-derived granite connection in thickened orogens. Earth Sci. /tev.,36:83-130

Dantas, E.L.; Cordani, U.G.; Van Schums, R.W.; Hackspacher, P.C.; Brito Neves, B.B.; Nutman, A.P. 1995. Terrenos arqueanos e paleoproterozóicos do maciço Calda Brandão na Província Borborema. In: Simpósio de Geologia do Nordeste, 16. Recife, 1995. Atas ... Recife, SBG. v. 2, p. 423-427.

De La Roche, H.; Leterrier, J.; Grandclaude, P. 1980. A classification of volcanic and plutonic rocks and associations. Chem. Geol., 29: 183-210.

Debon, F. \& LeFort, P. 1983. A chemical-mineralogical classification of common plutonic rocks and associations. Trans. R. Sac. Edin.: Earth Sci., 73: 135-149.

D'Lemos, R.S.; BROWN, M.; STRACHAN, R.A. 1992. Granite magma generation, ascent and emplacement within a transpressional orogen. Jour. Geol. Soc. London, 149: 487-490.

Etheridge, M. A.; Wall, V.J.; Vernon, R.H. 1983. The role of the fluid phase during regional metamorphism and deformation. J. Metam. Geol., 1: 205-226.
Galindo, A.C.; Dall'Agnol, R.; McReath, I.; Lafon, J.M.; Teixeira, N. 1995. Evolution of Brasiliano-age granitoid types in a shear zone environment, Umarizal-Carnaúbas region, Rio Grande do Norte, northeast Brazil. Jour. South American Earth Sci., 8: region,

Galindo, A.C.; Jardim de Sá, E.F.; Fonseca, A.S.S.; Leterrier, J. 1997. The Itaporanga-type granites in the Seridó Belt: monzonitic plutonism related to an oblique collisional orogen. In: International Symposium Granites and Associated Mineralization, 2. Salvador, 1997. Ext. Abstr... Salvador, SBG/SGM-BA, p. 202-203.

Gulson, B.L.; Lovering, J.F.; Taylor, S.R.; White, J.R. 1972. High-K diorites, their place in the calc-alkalic association and relationship to andesites. Lithos, 5: 269-279.

Hollanda, M.H.B.M. 1998. Mecanismos de alojamento de magmas granitóides: exemplo do Plúton de Japi (RN). Natal. 120 p. (Dissertação de Mestrado, Programa de Pesquisa e Pós-Graduação em Geodinâmica e Geofísica, Universidade Federal do Rio Grande do Norte).

Hollanda, M.H.B.M.; Jardim de Sá, E.F.; Galindo, A.C.; Souza, Z.S. 1996. Alojamento de magmas em zonas transcorrentes: o exemplo do plúton de Japi (Faixa Seridó), RN. In: Congresso Brasileiro de Geologia, 39. Salvador, 1996. Anais ... Salvador, SBG. v. 1 , p. 444-446.

Hollanda, M.H.B.M.; Medeiros, W.E.; Jardim de Sá, E.F; Moreira, J.A.M.; Castro, D.L. 1997. Modelo da geometria e mecanismo de alojamento do plúton de Japi (RN), a partir da combinação de dados estruturais e gravimétricos. In: Simpósio Nacional de Estudos Tectônicos, 6. Pirenópolis, 1997. Boi. Rés. Exp. ... Brasília, SBG. v. 1, p. $275-276$ 
Jardim de Sá, E.F. 1994. A Faixa Seridó (Província Borborema, NE do Brasil) e o seu significado geodinâmico na Cadeia Brasiliana/ Pan-Africana. Brasília. $804 \mathrm{p}$ (Tese de Doutorado, Instituto de Geociências da Universidade de Brasília).

Jardim de Sá, E.F. 1995. A Faixa Seridó (Província Borborema, NE do Brasil) e o seu significado geodinâmico na Cadeia Brasiliana/Pan-Africana. In: Simpósio de Geologia do Nordeste, 16. Recife, 1995. Atas ... Recife, SBG. v. 2, p. 394-398

Jardim de Sá, E.F.; Legrand, J.M.; Galindo, A.C.; Sá, J.M.; Hackspacher, P.C. 1986. Granitogênese brasiliana no Seridó: o maciço de Acari (RN). Rev. Bras. Geoc., 16 95-105.

Jardim de Sá, E.F.; Macedo, M.H.F.; Fuck, R.A.; Van Schmus, W.R.; Dantas, E.L. 1996 Fonte mantélica enriquecida na Faixa Seridó (Nordeste do Brasil): implicações na geodinâmica brasiliana. In: Congresso Brasileiro de Geologia, 39. Salvador, 1996. Anais ... Salvador, SBG. v. 7, p. 502-504
Jardim de Sá, E.F.; Macedo, M.H.F.; Legrand, J.M.; MCreath, L; Galindo, A.C.; Sá, J.M. 1987. Proterozoic granitoids in a polycyclic setting: the Seridó region, NE Brazil. In: International Symposium Granites and Associated Mineralization, 1. Salvador, 1987. Ext. Abstr... Salvador, SBG/SGM-BA, p. 103-110.

Lameyre, J. 1987. Granites and evolution of the crust. Rev. Bras. Geoc., 17: 349-359. LeMaitre, R.W. 1976. Some problems of the projection of chemical data into mineralogical classifications. Conn. Miner. Petrol., 56: 181-189.

Sial, A.N. \& Ferreira, V.P. 1988. Brasiliano age peralkalic plutonic rocks of the Central structural domain, NE Brazil. Rendic. Soc. Ital. Miner. Petrol., 43: 307-342.

Manuscrito A-1049

Recebido em 10 dezembro de 1997 Revisão dos autores emlS de agosto de 1998 Revisão aceita em30 de agosto de 1998 